\title{
Empowerment extent of women entrepreneurs
}

\author{
SEEMAPRAKALPA* \\ Department of Home Science Extension, Dr. B.R. Ambedkar University, AGRA (U.P.) INDIA \\ (Email : prakalpass@gmail.com)
}

\begin{abstract}
Empowerment implies a state of mind and attitude of a person. The aim of present study was to explore extent of empowerment of women entrepreneurs. Descriptive type of research design was used to study three indicators of empowerment namely decision-making, sense of personal efficacy and achievements after venturing an enterprise of 60 women entrepreneurs running boutique/beauty parlour. For assessing decision-making, decision-making index was developed. To measure sense of personal efficacy an inventory of thoughts and tendencies consisting of appropriate statements devised by Prayag Mehta (1995) was used. For assessing achievements after running enterprise, full freedom was given to the entrepreneurs to express their achievements. Primary data were collected through interview schedule in zones of Agra city in U.P. during 2005. Percentage was used as a statistical measure .The study showed that entrepreneurs were taking decisions related to economic security, making heavy purchases, daily purchases, mobility in reference of enterprise and major decisions relating to the enterprise and possessing average sense of personal efficacy. Entrepreneurs expressed achievements, which were increase in self-confidence, taking immediate decisions; increase in recognition, become self-dependent and increase in their self-respect. The findings of the study are based on expressed opinions of the entrepreneurs. Hence, the objectivity would be limited to the extent of the entrepreneurs' honest opinions. In spite of this limitation, it is hoped that the findings of this study would provide a better insight in preparing the future plan for empowering women.
\end{abstract}

KeY WoRDS : Empowerment, Decision-making, Sense of personal efficacy, Entrepreneurship

View Point Article : Seemaprakalpa (2014). Empowerment extent of women entrepreneurs. Internat. J. Home. Sci. Extn. \& Comm. Mgmt., 1 (2): 91-96.

Article History : Received : 01.05.2014; Revised : 25.05.2014; Accepted : 04.06.2014

\footnotetext{
* Author for correspondence
} 